\title{
Prevention and conduct against the Extravasation of antineoplastic chemotherapy: a scoping review
}

\author{
Prevenção e conduta frente ao Extravasamento de agentes antineoplásicos: scoping review
}

Prevención y conducta ante la Extravasación de quimioterápicos antineoplásicos: scoping review

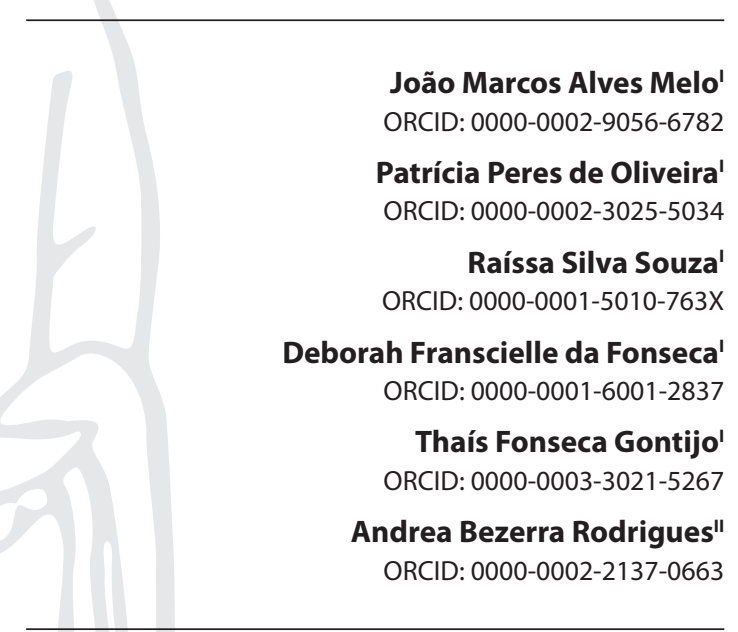

'Universidade Federal de São João del-Rei. Divinópolis, Minas Gerais, Brazil.

"Universidade Federal do Ceará. Fortaleza, Ceará, Brazil.

How to cite this article: Melo JMA, Oliveira PP, Souza RS, Fonseca DF, Gontijo TF, Rodrigues AB. Prevention and conduct before the Extravasation of antineoplastic chemotherapy: scoping review. Rev Bras Enferm. 2020;73(4):e20190008.

doi: http://dx.doi.org/10.1590/0034-7167-2019-0008

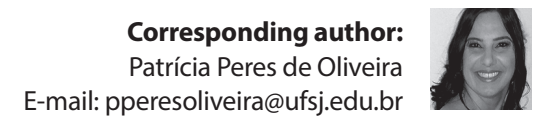

EDITOR IN CHIEF: Antonio José de Almeida Filho ASSOCIATE EDITOR: Hugo Fernandes

Submission: 02-19-2019 Approval: 08-13-2019

\begin{abstract}
Objectives: to identify and synthesize scientific evidence on prevention and management of extravasation of antineoplastic agents in adult patients by nurses. Methods: scoping review, according to Joanna Briggs Institute and PRISMA-ScR. Research was conducted in five electronic databases, Cochrane Library and eight catalogs of theses and dissertations. Data collection occurred from April to July 2018, with no time limit. The extracted data were analyzed and synthesized in a narrative way. Results: a total of 3,110 records were retrieved and 18 studies were kept for review. Most publications (66.6\%) had a qualitative approach and addressed both aspects, i.e., prevention and management of extravasation of chemotherapy in adult patients. Conclusions: the implementation of protocols based on scientific evidence on prevention and management of extravasation of antineoplastic agents is paramount in order to provide patient safety and support to the nursing staff. Descriptors: Combined Chemotherapy; Antineoplastic Agents; Nursing Care; Extravasation of Therapeutic and Diagnostic Materials; Oncology.
\end{abstract}

\section{RESUMO}

Objetivos: identificar e sintetizar as evidências científicas sobre prevenção e conduta do extravasamento de agentes antineoplásicos em pacientes adultos realizado por enfermeiros. Métodos: scoping review, conforme Joanna Briggs Institute e o PRISMA-ScR. Realizou-se pesquisa em cinco bases de dados eletrônicas, na Biblioteca Cochrane e em oito catálogos de teses e dissertações. A coleta de dados ocorreu de abril a julho de 2018, sem limite temporal. Os dados extraídos foram analisados e sintetizados de forma narrativa. Resultados: foram recuperados um total de 3.110 registros e mantidos 18 estudos para a revisão. A maioria das publicações $(66,6 \%)$ tinha abordagem qualitativa e apresentaram as duas vertentes, ou seja, prevenção e conduta frente ao extravasamento de quimioterapia em pacientes adultos. Conclusões: é primordial a implementação de protocolos baseados na evidência científica sobre prevenção e conduta diante do extravasamento de antineoplásicos a fim de fornecer segurança ao paciente e respaldo à equipe de enfermagem.

Descritores: Quimioterapia Combinada; Antineoplásicos; Cuidados de Enfermagem; Extravasamento de Materiais Terapêuticos e Diagnósticos; Oncologia.

\section{RESUMEN}

Objetivos: identificar y sintetizar evidencia científica sobre prevención y manejo de fugas de agentes antineoplásicos en pacientes adultos por parte de enfermeras. Métodos: revisión del alcance, según el Instituto Joanna Briggs y PRISMA-ScR. La investigación se realizó en cinco bases de datos electrónicas, la Biblioteca Cochrane y ocho catálogos de tesis y disertaciones. La recopilación de datos se produjo de abril a julio de 2018, sin límite de tiempo. Los datos extraídos fueron analizados y sintetizados en forma narrativa. Resultados: se recuperaron un total de 3.110 registros y se conservaron 18 estudios para su revisión. La mayoría de las publicaciones $(66,6 \%)$ tenían un enfoque cualitativo y abordaban ambos aspectos, es decir, la prevención y el tratamiento contra la extravasación de quimioterapia en pacientes adultos. Conclusiones: la implementación de protocolos basados en evidencia científica sobre prevención y manejo de la fuga antineoplásica es primordial para proporcionar seguridad al paciente y apoyo al personal de enfermería.

Descriptores: Quimioterapia Combinada; Antineoplásicos; Atención de Enfermería; Extravasación de Materiales Terapéuticos y Diagnósticos; Oncología Médica. 


\section{INTRODUCTION}

Malignant neoplasm has become a health problem worldwide due to its epidemiological, social and economic magnitude. According to data from the World Health Organization (WHO) International Agency for Research on Cancer (IARC), the incidence in the world has grown by $20 \%$ in the last decade ${ }^{(1)}$. It is estimated that by 2030 , the number of people affected by this comorbidity in the world will be around 21.4 million. Thirteen point two million will die due to the impact of changes in sociodemographic and epidemiological patterns of the world's population ${ }^{(2)}$. In Brazil, the estimate for the 2018-2019 biennium will be 600,000 new cases of cancer each year ${ }^{(3)}$.

The intervention and treatment process for cancer patients is complex, multidisciplinary and mainly depends on their clinical staging, tumor pathological characteristics and predictive and prognostic factors $^{(2-3)}$.

For this disease, there are numerous modalities of tumor eradication interventions that can be used alone or in combination, especially chemotherapy (CT), which acts in the cell cycle and division, interrupting the proliferation of cells ${ }^{(4-6)}$.

Intravenous treatment with CT can lead to multiple adverse events, including extravasation, especially vesicant and irritant drugs. Extravasation can be described as accidental extravasation of the drug or blood vessel solution into adjacent tissues, which can lead to tissue damage, including necrosis and often limiting sequel ${ }^{(7-8)}$.

Statistically, the incidence of extravasation is low, and it is estimated that $0.01 \%$ to $6.5 \%$ of all cytotoxic drug administrations result in extravasation. However, when assessing the number of adverse events associated with CT, such as sepsis, neutropenia, mucositis and gastrointestinal disorders, the absolute number of extravasations becomes significant. The result can be potentially devastating, with long-term consequences such as nerve damage or the need for reconstructive surgery with the potential to be even more debilitating for the patient than their primary disease ${ }^{(9)}$.

Dermatological toxicity resulting from the extravasation of antineoplastic agents is one of the main adverse events that demand greater care rigor from the oncology nurse. Plays a key role in preventing, identifying and monitoring the complications of adverse events (AE). Intervention before extravasation requires updated theoretical and practical grounding ${ }^{(7-8)}$, since safety in the process of administering chemotherapeutic agents is part of nursing's daily life, being its responsibility ${ }^{(10)}$.

Given the above, the prevention of this AE and the management of its occurrence is fundamental to the quality of care provided, since the extravasation of antineoplastic agents is a serious complication that causes stress in the nursing staff and can cause patient damage.

The relevance of this study is to provide a mapping of the main prevention actions and behaviors regarding the extravasation of $\mathrm{CT}$, in order to provide subsidies for the practice of cancer nursing. It is noteworthy that specialist oncology nurses need to be aware of the most current evidence (or lack of evidence) regarding prevention, detection, management, documentation and management of extravasation of antineoplastic agents.

\section{OBJECTIVES}

To identify and synthesize scientific evidence on prevention and management of extravasation of antineoplastic agents in adult patients by nurses.

\section{METHODS}

\section{Ethical aspects}

No ethical appraisal was required as it was a study with public domain data.

\section{Type of study}

This is a scoping review with a research protocol registered with the Open Science Framework (https://osf.io/8b9pz/). It was developed based on the recommendations of the PRISMA-ScR International Guide ${ }^{(11)}$ and the method proposed by the Joanna Briggs Institute, Reviewers Manual 2017(12), which establishes five steps, namely: 1) identification of the research question; 2) identification of relevant studies; 3) study selection; 4) data analysis; 5) grouping, synthesis and presentation of data ${ }^{(12-13)}$.

This review modality is a type of knowledge synthesis, following a systematic approach to map evidence on a topic and identify key concepts, theories, sources and knowledge gaps ${ }^{(11-13)}$.

The participants, concept and context (PCC) strategy (12) was used to construct the research question, in which $\mathrm{P}$ (participants) - adult cancer patients, $C$ (concept) - prevention and conduct performed by nurses regarding the extravasation of CT and $C$ (context) - administration of CT. Thus, the established research questions were: what nursing care is relevant, in the context of CT administration, in the prevention of extravasation of CT in adult cancer patients? What are the important nursing practices regarding the extravasation of antineoplastic agents in adult cancer patients?

\section{Data source and search strategy}

Initially, a search was conducted on the PubMed portal and the Cumulative Index to Nursing and Allied Health Literature (CINAHL) database to identify the main descriptors and keywords used in studies that address the topic of interest from the combination of MeSH Identified for Research Mneumonic. They were: Antineoplastic Agents [Mesh] OR Drug Therapy [Mesh] OR Chemotherapy, Adjuvant [Mesh] OR Induction Chemotherapy [Mesh] OR Consolidation Chemotherapy [Mesh] OR Maintenance Chemotherapy [Mesh] OR Medication Therapy Management [Mesh] OR Administration AND Dosage [Mesh] OR Antineoplastic Combined Chemotherapy Protocols [Mesh] AND patient care bundles OR nursing care [Mesh] OR Accident Prevention [Mesh] AND Extravasation of Diagnostic and Therapeutic Materials [Mesh] OR Injection Site Reaction [Mesh].

Therefore, the final defined search strategy was: (Antineoplastic Agents OR Drug Therapy OR Chemotherapy Adjuvant OR Induction Chemotherapy OR Consolidation Chemotherapy OR Maintenance Chemotherapy OR Medication Therapy Management OR Administration and Dosage OR Antineoplastic Combined Chemotherapy Protocols) AND (patient care bundles OR nursing care OR Accident Prevention) AND (Extravasation of Diagnostic and Therapeutic Materials OR Injection Site Reaction). 
After the descriptors and synonyms were selected, the studies were searched electronically in the National Library of Medicine and National Institutes of Health (PUBMED), CINAHL, Web of Science, SCOPUS, Latin American \& Caribbean Health Sciences Literature (LILACS), Cochrane Library databases. They were also searched in the Theses and Dissertations Catalog of the Coordination for the Improvement of Higher Education Personnel (CAPES - Coordenação de Aperfeiçoamento de Pessoal do Nível Superior); Europe E-Theses Portal (DART); Electronic Theses Online Service (EThOS); Open Access Scientific Repository of Portugal (RCAAP - Repositório Científico de Acesso Aberto de Portugal); National ETD Portal; Theses Canada, Latin American Thesis Portal and World Cat Dissertations and Theses.

It is worth noting that for all the bases listed above, the standardization of the search occurred through CAPES Journal Portal use, through the Federated Academic Community (CAFe-Comunidade Acadêmica Federada). Access was selected from Universidade Federal de São João del-Rei (UFSJ) and by the Online Catalog of the SIGAA Library Module of the Universidade Federal do Rio Grande do Norte.

\section{Collection and organization of data}

The search was performed from April to July 2018. Articles published in Portuguese, English or Spanish, with full texts available online in the selected databases; that addressed preventive measures and conduct for extravasation of $\mathrm{CT}$ performed by nurses regarding extravasation of $C T$ in adult patients, with no time limit for publication of articles were included.

Articles that do not include the guiding question, conference abstracts and annals, comments, editorials, expert opinions, single case study, previous notes and reports, as well as narrative and integrative reviews; that only addressed evaluations and interventions performed by dermatologists and surgeons were excluded.

\section{Data analysis}

The titles and abstracts of the articles retrieved in the search were read and analyzed by the authors, who worked in pairs, to identify those potentially eligible for the study. While there was no consensus among reviewers, the article was kept in the database for the next phase. It involved the full reading of each of the articles selected by two independent reviewers aiming at a) confirming the pertinence to the guiding question of the research and, if so, b) extracting the data of interest. Inconsistencies or doubts were resolved by consensus among the authors.

For the separation, summarization and reporting of the essential elements found in each study, a structured tool was used. This tool allowed the synthesis, interpretation of data and basic numerical analysis of the extent, nature and distribution of studies incorporated in the review $^{(14)}$. Items such as type of study (article, dissertation or thesis), year of publication, country of origin, objectives, method, description of care used for prevention and/or conduct regarding the extravasation of antineoplastic agents and the conclusions were grouped.

Thus, in each publication were identified and extracted the fundamental cores involved in the conjecture of the problem, in the contexts, methods, discussions and conclusions. The fundamental nuclei were analyzed, turning to the full texts, when necessary, being identified categories of analysis that allowed narrative synthesis of the findings. Descriptive statistics was used for material analysis, using absolute and relative frequency calculations.

Finally, the synthesis and presentation of the results took place, with the intention of presenting the overview of all the material, through a thematic construction. One was focused on ways to prevent and the other that systematically brought the conducts facing the $\mathrm{AE}$ of the extravasation of antineoplastic agents.

\section{RESULTS}

The initial search in the databases generated a total of 3,110 studies. In the first screening, 49 studies were pre-selected, of which 11 duplicate studies were excluded; 20 publications did not answer the research question. Therefore, 16 articles and two master's dissertations remained, which were included in the main analysis. Thus, the sample of this review consisted of 18 studies.

Figure 1 shows the process of searching, deleting and selecting the studies found.

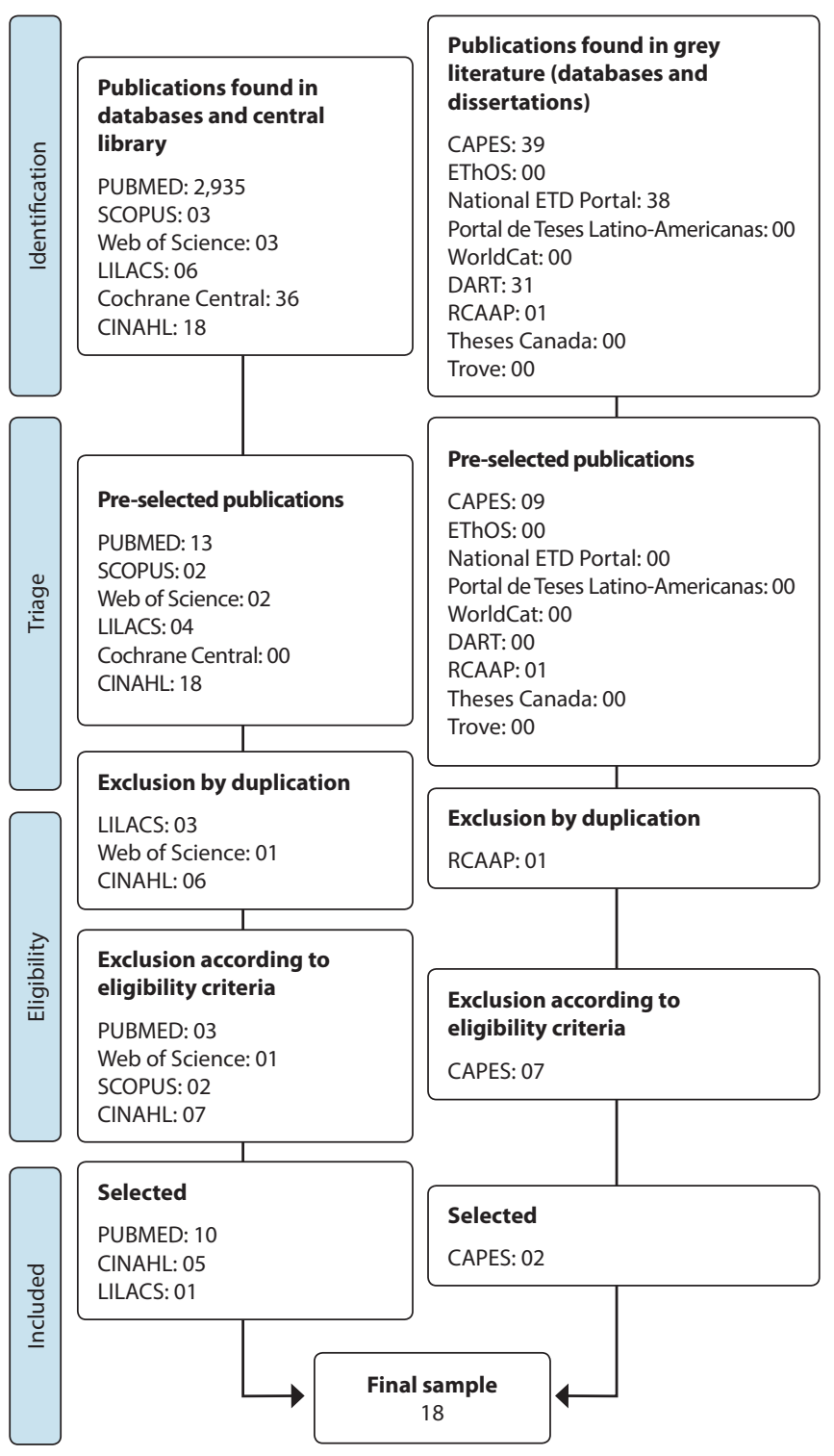

Figure 1 - Scoping Review Study Flow Process Adapted from PRISMA-ScR (11), Divinópolis, Minas Gerais, Brazil, 2018 
The results were presented descriptively in figure and tables. It was used as base the analysis of elements related to the nature of the studies, the year and the region/country of the papers, periodicals responsible for the publication of the articles or institution where the thesis or dissertation was defended, main results in relation to the prevention and conduct the extravasation of antineoplastic agents of the study.

The following are the research variables, which were organized according to the methodological approach of the works, i.e., 12
(66.6\%) were quantitative (Chart 1), one of them (5.6\%) qualitative (Chart 2) and five (27.8\%) with mixed approach (Chart 3).

The articles had several nationalities: United Kingdom ${ }^{(18-21,26,31)}$, Brazil $^{(16-17,22-23)}$, United States of America ${ }^{(9,25)}$ Japan $^{(15)}$, Greece ${ }^{(24)}$, Italy ${ }^{(27)}$, Austria $^{(20)}$, Germany ${ }^{(29)}$ and Spain ${ }^{(30)}$. In the present review, the United Kingdom was the country with the largest number of retrieved searches (33.3\%), followed by Brazil with four (22.2\%) and the United States with two articles (11.2\%) and the other countries with a study.

Chart 1 - Characterization of publications with a quantitative approach on prevention and management of extravasation in the administration of antineoplastic agents, Divinópolis, Minas Gerais, Brazil, 2018

\begin{tabular}{|c|c|c|c|c|}
\hline Author(s) & Year & Type / Title & $\begin{array}{l}\text { Journal or } \\
\text { institution }\end{array}$ & Objective(s) \\
\hline $\begin{array}{l}\text { Jackson-Rose J, Del } \\
\text { Monte J, Groman } \\
\text { A, Dial LS, Atwell L, } \\
\text { Graham J, et al }{ }^{(9)}\end{array}$ & 2017 & $\begin{array}{l}\text { Article / Chemotherapy } \\
\text { extravasation: } \\
\text { establishing a national benchmark } \\
\text { for incidence among cancer centers }\end{array}$ & $\begin{array}{l}\text { Clinical Journal } \\
\text { of Oncology } \\
\text { Nursing }\end{array}$ & $\begin{array}{l}\text { - To evaluate vesicant extravasation of CT in adult cancer } \\
\text { patients }(739,812 \text { doses of vesicant and irritant } C T \text { infusions } \\
\text { were included in the evaluation of } 11 \text { cancer services); } \\
\text { - To report the incidence of extravasation of vesicants and } \\
\text { irritants with potential vesicant. }\end{array}$ \\
\hline $\begin{array}{l}\text { Matsui Y, } \\
\text { Murayama R, Tanabe } \\
\text { H, Oe M, Motoo Y, } \\
\text { Wagatsuma T, } \\
\text { et al }{ }^{(15)}\end{array}$ & 2017 & $\begin{array}{l}\text { Article / Evaluation of the } \\
\text { predictive validity of thermography } \\
\text { in identifying extravasation } \\
\text { with intravenous chemotherapy } \\
\text { infusions }\end{array}$ & $\begin{array}{l}\text { Journal of } \\
\text { Infusion } \\
\text { Nursing }\end{array}$ & $\begin{array}{l}\text { - To evaluate the predictive validity of thermography to } \\
\text { identify extravasation during intravenous antineoplastic } \\
\text { therapy. }\end{array}$ \\
\hline Custódio CS (16) & 2016 & $\begin{array}{l}\text { Dissertation / Injurias vasculares } \\
\text { relacionadas a infusão periférica de } \\
\text { quimioterapia em mulheres com câncer } \\
\text { de mama: estudo longitudinal }\end{array}$ & $\begin{array}{l}\text { Repository of } \\
\text { UnB }\end{array}$ & $\begin{array}{l}\text { - To evaluate changes in peripheral veins used for } \\
\text { chemotherapy infusion in breast cancer patients over the } \\
\text { course of treatment and to describe care and guidance in } \\
\text { choosing venous access for CT infusion. }\end{array}$ \\
\hline Freitas $\mathrm{KABS}^{(17)}$ & 2015 & $\begin{array}{l}\text { Dissertation / Estratégias } \\
\text { para administração segura de } \\
\text { antineoplásicos }\end{array}$ & $\begin{array}{l}\text { Institutional } \\
\text { Repository } \\
\text { of UNESP }\end{array}$ & $\begin{array}{l}\text { - To trace the profile and knowledge in CT of inpatient nurses } \\
\text { of a University Hospital and develop strategies for safe } \\
\text { administration of antineoplastic drugs. }\end{array}$ \\
\hline $\begin{array}{l}\text { Harrold K, Gould D, } \\
\text { Drey N }{ }^{(18)}\end{array}$ & 2015 & $\begin{array}{l}\text { Article / The management of cytotoxic } \\
\text { chemotherapy extravasation: a } \\
\text { systematic review of the literature to } \\
\text { evaluate the evidence underpinning } \\
\text { contemporary practice }\end{array}$ & $\begin{array}{l}\text { European } \\
\text { Journal of } \\
\text { Oncology } \\
\text { Nursing }\end{array}$ & $\begin{array}{l}\text { - To critically analyze the quality of evidence supporting } \\
\text { contemporary practice of extravasation of CT management } \\
\text { and to verify whether patient experience is taken into } \\
\text { account in relation to extravasation of CT management. }\end{array}$ \\
\hline $\begin{array}{c}\text { Muthuramalingam S, } \\
\text { Gale J, } \\
\text { Bradbury J(19) }\end{array}$ & 2013 & $\begin{array}{l}\text { Article / Dexrazoxane efficacy for } \\
\text { anthracycline extravasation: use in } \\
\text { UK clinical practice }\end{array}$ & $\begin{array}{l}\text { International } \\
\text { Journal of } \\
\text { Clinical Practice }\end{array}$ & $\begin{array}{l}\text { - To report UK case review (102) on the efficacy of } \\
\text { Dexrazoxane for the treatment of anthracycline extravasation. }\end{array}$ \\
\hline $\begin{array}{l}\text { Harrold K, Gould D, } \\
\text { Drey N }\end{array}$ & 2013 & $\begin{array}{l}\text { Article / The efficacy of saline } \\
\text { washout technique in the } \\
\text { management of exfoliant } \\
\text { and vesicant chemotherapy } \\
\text { extravasation: a historical case series } \\
\text { report }\end{array}$ & $\begin{array}{l}\text { European } \\
\text { Journal of } \\
\text { Cancer Care }\end{array}$ & $\begin{array}{l}\text { - To present the results of a historical case series of } \\
\text { extravasation of } C T \text { administered by saline washout and; } \\
\text { evaluate the effectiveness of the procedure based on patient } \\
\text { outcome. }\end{array}$ \\
\hline Drake $D^{(21)}$ & 2012 & $\begin{array}{l}\text { Article / Emergency management } \\
\text { of anthracycline extravasation }\end{array}$ & $\begin{array}{l}\text { Emergency } \\
\text { Medicine } \\
\text { Journal }\end{array}$ & $\begin{array}{l}\text { - To establish that intravenous dexrazoxane reduces the risk } \\
\text { of tissue necrosis following anthracycline chemotherapy } \\
\text { extraction. }\end{array}$ \\
\hline $\begin{array}{l}\text { Schneider, F; Pedrolo, } \\
\text { E. }{ }^{(22)}\end{array}$ & 2011 & $\begin{array}{l}\text { Article / Extravasamento de } \\
\text { drogas antineoplásicas: avaliação } \\
\text { do conhecimento da equipe de } \\
\text { enfermagem }\end{array}$ & $\begin{array}{l}\text { Revista Mineira } \\
\text { de Enfermagem }\end{array}$ & $\begin{array}{l}\text { - To point out the importance of improvement in service and } \\
\text { the elaboration of a clinical guideline, so that professionals } \\
\text { can identify patients at higher risk of extravasation of CT, } \\
\text { promote prevention and damage minimization actions. }\end{array}$ \\
\hline $\begin{array}{l}\text { Adami NP, de } \\
\text { Gutiérrez MG, da } \\
\text { Fonseca SM, de } \\
\text { Almeida EP(23) }\end{array}$ & 2005 & $\begin{array}{l}\text { Article / Risk management of } \\
\text { extravasation of cytostatic drugs at } \\
\text { the adult chemotherapy outpatient } \\
\text { clinic of a University Hospital }\end{array}$ & $\begin{array}{l}\text { Journal of } \\
\text { Clinical Nursing }\end{array}$ & $\begin{array}{l}\text { - To check the incidence of antineoplastic drug extravasation in } \\
\text { outpatients treated at a university hospital for five years and to } \\
\text { evaluate the quality of care provided by the nursing staff. }\end{array}$ \\
\hline $\begin{array}{c}\text { Tsavaris NB, } \\
\text { Komitsopoulou } \\
\text { P, Karagiaouris P, } \\
\text { Loukatou P, Tzannou I, } \\
\text { Mylonakis N, et al(24) }\end{array}$ & 1992 & $\begin{array}{l}\text { Article / Prevention of tissue } \\
\text { necrosis due to accidental } \\
\text { extravasation of cytostatic drugs by } \\
\text { a conservative approach }\end{array}$ & $\begin{array}{l}\text { Cancer } \\
\text { Chemotherapy } \\
\text { and Pharmacy }\end{array}$ & $\begin{array}{l}\text { - To comparatively evaluate the effectiveness of a } \\
\text { conservative approach to treatment using two therapeutic } \\
\text { regimens (with or without sodium thiosulfate). }\end{array}$ \\
\hline $\begin{array}{c}\text { Olver IN, Aisner J, } \\
\text { Hament A, Buchanan } \\
\text { L, Bishop JF, } \\
\text { Kaplan } \mathrm{RS}^{(25)}\end{array}$ & 1988 & $\begin{array}{l}\text { Article / A prospective study } \\
\text { of topical dimethyl sulfoxide } \\
\text { for treating anthracycline } \\
\text { extravasation }\end{array}$ & $\begin{array}{l}\text { Journal } \\
\text { of Clinical } \\
\text { Oncology }\end{array}$ & $\begin{array}{l}\text { - To introduce anthracycline extravasation treatment with } \\
99 \% \text { topical dimethyl sulfoxide (DMSO) over a three-month } \\
\text { period with regular examinations and photographs. }\end{array}$ \\
\hline
\end{tabular}

Note: $C T$ - chemotherapy. 
Chart 2 - Characterization of publications, with a qualitative approach, on prevention and management before extravasation in the administration of antineoplastic agents, Divinópolis, Minas Gerais, Brazil, 2018

\begin{tabular}{|c|c|l|c|l|}
\hline Author(s) & Year & \multicolumn{1}{|c|}{ Type/Title } & $\begin{array}{c}\text { Journal or } \\
\text { institution }\end{array}$ & \multicolumn{1}{c|}{ Objective(s) } \\
\hline $\begin{array}{c}\text { Dougherty L, } \\
\text { Oakley C(26) }\end{array}$ & 2011 & $\begin{array}{l}\text { Article / Advanced practice } \\
\text { in the management of } \\
\text { extravasation }\end{array}$ & $\begin{array}{l}\text { Cancer } \\
\text { Nursing } \\
\text { Practice }\end{array}$ & $\begin{array}{l}\text { - To describe flush-out training for nurses to provide more timely } \\
\text { and less inconvenient interventions for patients. }\end{array}$ \\
\hline
\end{tabular}

Chart 3 - Presentation of publications with mixed approach on prevention and management of extravasation in the administration of antineoplastic agents, Divinópolis, Minas Gerais, Brazil, 2018

\begin{tabular}{|c|c|c|c|c|}
\hline Author(s) & Year & Type/Title & $\begin{array}{l}\text { Journal or } \\
\text { institution }\end{array}$ & Objective(s) \\
\hline $\begin{array}{l}\text { Onesti MG, Carella } \\
\text { S, Fioramonti } \mathrm{P} \\
\text { Scuderi } \mathrm{N}^{(27)}\end{array}$ & 2017 & $\begin{array}{l}\text { Article / Chemotherapy Extrav- } \\
\text { asation Management: } 21 \text {-Year } \\
\text { Experience }\end{array}$ & $\begin{array}{l}\text { Annals of } \\
\text { Plastic Surgery }\end{array}$ & $\begin{array}{l}\text { - To explore prevention and treatment of extravasation injuries by } \\
\text { proposing a standard therapeutic protocol along with a literature } \\
\text { review. }\end{array}$ \\
\hline $\begin{array}{l}\text { Pluschnig U, Haslik } \\
\text { W, Bayer G, Solei- } \\
\text { man A, Bartsch R, } \\
\text { Lamm W, et al }{ }^{(28)}\end{array}$ & 2015 & $\begin{array}{l}\text { Article / Outcome of chemo- } \\
\text { therapy extravasation in a large } \\
\text { patient series using a stan- } \\
\text { dardised management protocol }\end{array}$ & $\begin{array}{l}\text { Support Care } \\
\text { Cancer }\end{array}$ & $\begin{array}{l}\text { - To observe the extravasation of antineoplastic agents from } 169 \\
\text { patients and evaluate the effectiveness of their interdisciplinary } \\
\text { management in a single research setting. }\end{array}$ \\
\hline $\begin{array}{l}\text { de Wit M, Ortner P, } \\
\text { Lipp HP, Sehouli J, } \\
\text { Untch M, Ruhnke } \\
\text { M, et al }{ }^{(29)}\end{array}$ & 2013 & $\begin{array}{l}\text { Article / Management of cy- } \\
\text { totoxic extravasation - ASORS } \\
\text { expert opinion for diagnosis, } \\
\text { prevention and treatment }\end{array}$ & Onkologie & $\begin{array}{l}\text { - To review and discuss the practice in the diagnosis and manage- } \\
\text { ment of extravasation of CT. }\end{array}$ \\
\hline $\begin{array}{l}\text { Pérez Fidalgo JA, } \\
\text { García Fabregat } L, \\
\text { Cervantes A, } \\
\text { et al }{ }^{(30)}\end{array}$ & 2012 & $\begin{array}{l}\text { Article / Management of } \\
\text { chemotherapy extravasation: } \\
\text { ESMO-EONS Clinical Practice } \\
\text { Guidelines }\end{array}$ & $\begin{array}{l}\text { European } \\
\text { Journal of } \\
\text { Oncology } \\
\text { Nursing }\end{array}$ & $\begin{array}{l}\text { - To introduce the European Society for Medical Oncology Guide- } \\
\text { lines published in cooperation with the European Oncology Nurs- } \\
\text { ing Society (EONS). }\end{array}$ \\
\hline $\begin{array}{l}\text { Wengström Y, } \\
\text { Margulies A, Eu- } \\
\text { ropean Oncology } \\
\text { Nursing Society } \\
\text { Task Force }\end{array}$ & 2008 & $\begin{array}{l}\text { Article / European Oncology } \\
\text { Nursing Society extravasation } \\
\text { guidelines. }\end{array}$ & $\begin{array}{l}\text { European } \\
\text { Journal of } \\
\text { Oncology } \\
\text { Nursing }\end{array}$ & $\begin{array}{l}\text { - To introduce European Oncology Nursing Society Guidelines for } \\
\text { prevention, detection, and management of extravasation. }\end{array}$ \\
\hline
\end{tabular}

Chart 4 - Description of prevention and management measures of extravasation of antineoplastic agents in adult patients by nurses found in the studies, Divinópolis, Minas Gerais, Brazil, 2018

\section{Prevention measures of the extravasation of antineoplastic agent in adults}

Beware of each individual's risk factors (threadlike and/or fragile veins, obesity, multiple previous venous punctures, presence of disseminated skin diseases (e.g., eczema or psoriasis), patient movement and level of consciousness $s^{(9,15,17,22,26,28,30)}$

Advise the patient to report any level of pain, burning, tingling or itching, which suggests perceptive infiltration, i.e., oriented to recognize extravasation ${ }^{(16-18,22,29-31)}$

Avoid puncture in limbs with loss of sensation, surgical manipulation site and previously irradiated limbs ${ }^{(16-17,22,26,30)}$

Avoid puncturing sites such as wrist, back of the hand and joints ${ }^{(15-17,22,28-31)}$

Avoid using piped peripheral access for more than 24 hours, preferring puncture at the moment ${ }^{(16-17,29-31)}$

Avoid using rigid devices for the administration of vesicant $\mathrm{CT}^{(17,22,30)}$

Always use as the ideal material for a peripheral venous catheter for CT administration: chemically inert, non-thrombogenic, flexible, radiopaque and transparent ${ }^{(17,22,30)}$
Chart 4

Secure venous access with means that make the puncture site visible $e^{(15,20)}$

Constantly assess for risk of peripheral venous extravasation ${ }^{(9,15-19,22,27-31)}$

Check blood flow after puncture and then flush with $10 \mathrm{ml}$ normal saline and check for signs of extravasation ${ }^{(29-30)}$.

Wash with 10 to $20 \mathrm{ml}$ saline between different anti-neoplastic drug infusions ${ }^{(30-31)}$

Check blood flow before CT is administered and regularly during bolus infusion ${ }^{(30-31)}$

Administer physiological solutions concomitantly with vesicant and / or irritant CT infusion ${ }^{(16,30-31)}$

Monitor the punctured access, both to assess its permeability, as well as for the quick visualization of possible reactions from vascular lesions or extravasation ${ }^{(9,15-17,30-31)}$

Contraindicating the use of bolus CT infusion pumps ${ }^{(17,30-31)}$

Training nursing staff and implementing CT overflow prevention protocols are crucial ${ }^{(9,16-17,22,28-30)}$

Recommend the use of central venous access for administration of vesicants or irritants ${ }^{(9,16-17,30)}$

Advise patients to obtain central venous access, where indicated, and provide informed consent on the risks and benefits of such access ${ }^{(9,29-30)}$ 
Chart 4 (concluded)

Conduct before the extravasation of antineoplastic agents in adults

Use the incidence of extravasation as a quality indicator ${ }^{(9,18,30)}$

Train nursing staff and implement conduct protocols in $\mathrm{CT}$ extravasations ${ }^{(20,22,26-28,30-31)}$

Remember that if an extravasation occurs, the degree of damage depends on the type of drug, the concentration of the drug, the site and how long a drug develops its potential for damage $\mathrm{e}^{(26,30-31)}$

Stopping CT infusion is the first measure when extravasation occurs or is suspected ${ }^{(9,17,22,27,30-31)}$

Beware for: In the event of a suspicious spill, treat it as a real event ${ }^{(9,30)}$

Perform drug aspiration, limb elevation and application of thermal compress (cold or heat) ${ }^{(17,20,22,27,30-31)}$

Demarcate and photograph CT overflow area ${ }^{(17,24-25,30-31)}$

Apply compress for 20 minutes four times a day for one or two days only for CT classified as Vinca Alkaloids ${ }^{(17,22,31)}$

Apply cold compresses to anthracycline extravasations, tumor antibiotics and alkylating agents. Only on oxaliplatin is heat applied ${ }^{(17,22-23)}$

Follow up CT extravasation (nurse and patient provider), whether actual or suspected extravasation ${ }^{(17,24,28,30-31)}$

Follow up the extravasation by phone or in person. On day 1, after the event and at least weekly (or more often as needed). Follow-up should continue for a period of three weeks to six weeks, or until complete resolution of extravasation is complete $\mathrm{e}^{(9,17,28,30)}$

Start as early as possible (up to 6 hours) dexrazoxane (Savene"), the only antidote licensed for the treatment of anthracycline extravasation ${ }^{(19-21,27,30-31)}$; administer intravenously into a vein in an area away from the extravasation site at a dose of $1000 \mathrm{mg} / \mathrm{m}^{2}$ day and two to $500 \mathrm{mg} / \mathrm{m}^{2}$ on day three ${ }^{(17-19,21,30)}$

Start topical DMSO as early as possible (99\%), preferably within 10 minutes if mitomycin $C$ is spilled. It should be applied every 8 hours for 7 days $^{(18,27-28,30)}$

Use sodium thiosulfate $0.17 \mathrm{M}$ (solution by mixing $4 \mathrm{~mL}$ sodium thiosulfate with $6 \mathrm{~mL}$ sterile water for injection) as a subcutaneous injection immediately if mechlorethamine is extravasated. Subcutaneous injection of $2 \mathrm{ml}$ solution made from $4 \mathrm{ml}$ sodium thiosulfate $+6 \mathrm{ml}$ sterile water ${ }^{(24,30-31)}$

Administer hyaluronidase by subcutaneous injection (150-900 IU around the extravasation area) in case of Vinca Alkaloid extravasation ${ }^{(28,30-31)}$ after application of dry heat for a period of seven days (three times daily) $)^{(28,30-31)}$

Administer subcutaneous injection hyaluronidase 150-900 UI around the taxane extravasation area ${ }^{(30)}$, without heat application after paclitaxel extravasation ${ }^{(28)}$

Beware not to use subcutaneous ${ }^{(28,30)}$ and topical corticosteroids in CT extravasations $\mathbf{s}^{(17,28,30)}$

Notify the patient's physician and a plastic surgeon should be consulted within 24 hours of detection of vesicant antineoplastic agent extravasation ${ }^{(28,30-31)}$

Document photographically (authorized in writing by the patient) and record the date, time, name of the extravasated drug, signs and symptoms, description of venous access, extravasation site, and the evolution of the case of CT extravasation ${ }^{(9,16-31)}$

Maintain an emergency overflow kit (containing at least procedure gloves, low-permeability apron, absorbent pads, respiratory and eye protection, soap, identified waste container) always available where antineoplastic agents are administered ${ }^{(18,29-31)}$

Note: i.e. - in essence; e.g. (exempligratia) - for example; CT - chemotherapy;DMSO-dimetilsulfóxido tópico; IU -International Units.
Regarding journals, only European Journal of Oncology Nursing $^{(18,30-31)}$ (impact factor 0.94, Journal Citation Reports 2017) had more than one article retrieved, the other articles were published in different health journals.

Regarding the theme of the studies, one ${ }^{(15)}$ of these brought measures to prevent extravasation of $\mathrm{CT}$ in its content. Five ${ }^{(20-21,23-25)}$ brought conducts regarding extravasation of $\mathrm{CT}$ in adult patients and $12^{(9,16-19,22,26-27-31)}$ of these addressed both prevention and behavioral approaches to extravasation of $\mathrm{CT}$. It is noteworthy that all prevention and conduct measures in the studies found in this research were performed by nurses specializing in oncology.

These were the categories for the communication of the results, namely: prevention of extravasation of antineoplastic agents in adult patients and the conduct of extravasation of CT in these people (Chart4).

\section{DISCUSSION}

This scoping review brought a small sample of cancer studies focused on the extravasation of antineoplastic agents in adults ${ }^{(18)}$. However, the research was of various nationalities, published in different scientific journals and graduate health institutions.

The analysis of the publications found revealed that specific work on prevention and conduct by oncology nurse specialists regarding the extravasation of antineoplastic agents in adult patients began in 1998. Although research on the topic found in the previous decade was found, it was not available in the databases and was therefore not included in the review. In 2013, 2015 and 2017 , the area reached the maximum number of papers on the theme published in one year (three), with eight articles ${ }^{(9,15,18-20,27-29)}$ and one dissertation ${ }^{(17)}$. In 2018, no study was retrieved, but this is a provisional number as the search was carried out in the middle of the year mentioned.

Thus, the number of publications did not follow a linear pattern over the years, which can be explained by the gradual reduction in the incidence of extravasation of CT. This is likely due to improvements in the administration procedure, early recognition of extravasation of drugs and training of oncology nurse specialists ${ }^{(30)}$ or underdiagnosis, undertreatment and underreporting of extravasation of CT in many cancer centers worldwide ${ }^{(26)}$.

Regarding the level of scientific evidence of the articles, most publications were derived from descriptive or qualitative study. Only one evidence was derived from a systematic review or meta-analysis of randomized controlled trials and none from a well-designed randomized controlled trial. Extravasation management remains empirical, based on descriptive studies. However, the lack of clinical trials can be explained by the difficulty in guaranteeing the validity and reliability, the multiplicity of variables and, mainly, the ethical considerations that make the use of a randomized control group impossible. This occurs in addition to the sample size requirements for quantitative studies of this nature to produce significant statistical results, due to the relatively small number and sporadic occurrence of extravasation of CT, making such research impossible ${ }^{(17-18,30)}$.

Vulnerabilities regarding extravasation according to the guidelines of the American Society of Clinical Oncology (ASCO), European Society of Medical Oncology (ESMO), Oncology Nursing Society (ONS) and European Oncology Nursing Society 
(EONS) are related to infused CT ( $\mathrm{pH}$, osmolarity, vasoconstrictor potential and time remaining in tissue). Also patient-related factors (tortuous veins, poor caliber, obesity, multiple previous venous punctures, presence of dermal alterations) and iatrogenic causes (such as lack of training of nurses, mistaken selection of peripheral catheter size and lack of time) ${ }^{(8)}$. Every effort should be made to reduce the risk of extravasation of CT. Personnel training, patient education, use of correct materials and infusion techniques have been identified as being required to minimize the risk of extravasation ${ }^{(29)}$.

It is noteworthy that the saline washout technique, described in two studies ${ }^{(20,26)}$, in light of the current best management strategy for extravasation of CT, found that there is a limited body of knowledge currently available on the efficacy of this technique (saline washout) as a therapeutic option for extravasation of $\mathrm{CT}^{(18,30)}$. It is a gap to be explored in future research.

The subcutaneous washout procedure is a surgical technique ${ }^{(29-30)}$ developed and performed by plastic surgeons in the United Kingdom ${ }^{(26)}$, therefore without indication for its performance by oncology specialist nurses in almost all countries, including Brazil.

The flush-out technique, which aims to release the drug from tissues, is a treatment of choice for extrusion of vesicant antineoplastic agents performed by ambulatory oncology nurse specialists. They are qualified and trained. Only at the South West London Cancer Network, South East London Cancer Network and Royal Surrey County Hospital do they perform such a procedure ${ }^{(26)}$.

Regarding the prevention of extravasation of antineoplastic agents, studies have shown the importance of leaving the patient informed about their treatment, that is, qualified for their treatment, including prevention of extravasation, as possible signs and symptoms, doubts and discomfort report to the nursing staff ${ }^{(16-18,22,29-31)}$. This makes clear the importance of the individual actively participating in their treatment.

It is emphasized that the prevention of extravasation of CT is an important quality indicator for certification of cancer services and is a shared responsibility among health team members ${ }^{(8)}$.

It was found that most studies have portrayed the importance of finding a suitable venipuncture site, taking into account the safety and body structures, being aware of the physiological conditions of each patient. Nurses need to be trained and attentive to a reliable assessment of patients undergoing parenteral $\mathrm{CT}^{(2,4-5,7,9,13)}$. Proper fixation of the venous catheter insertion site is brought by only two articles ${ }^{(15,20)}$. This is important as it avoids catheter dislocation and is a basic preventive measure, as well as making the puncture site visible.

Early detection and appropriate treatment of extravasation of CT is crucial to avoid the consequences of untreated or poorly managed extravasation. These may include bubble formation; skin peeling, which typically occurs one to two weeks after extravasation; tissue necrosis within two to three weeks after extravasation with resulting pain; in addition to damage to tendons, nerves and joints with possible functional and sensory impairment of the affected area ${ }^{(26,30)}$.

There is a clear consensus that the key factor in the effective management of extravasation of CT is the education of nurses, supported by up-to-date institutional policies and procedures for early detection ${ }^{(9,15-19,22,27-31)}$, in order to facilitate immediate intervention ${ }^{(9,16-31)}$. A study pointed out that thermography provides an accurate prediction of extravasation ${ }^{(15)}$, so it may be of great help to nurses.

The education and training of health professionals, especially nurses, are essential for good clinical practice, ensuring patient safety and being preventive rather than reactive to extravasation $^{(8,30)}$. Indeed, the Joint Commission International emphasizes the standards of proper management of $\mathrm{CT}^{(8)}$. Knowledge of international and national literature and guidelines is essential. Institutional policies need to be available and emphasize proper administration of antineoplastic agents and prevention of extravasation ${ }^{(8,19)}$.

The nurse specialist in oncology needs to have adequate scientific and technical knowledge to know how to act through these situations, be fully articulated with the team for good communication. Record in detail the extravasation of the drug and the close monitoring of this patient ${ }^{(9,15-19,22,27-31)}$, and notification to the Brazilian National Health Surveillance Agency (Agência Nacional de Vigilância Sanitária) ${ }^{(16-17)}$.

Regarding the infusion of bolus antineoplastic agents, the contraindication of the use of infusion pumps was evidenced, because the pressures exerted by this device may cause vessel rupture and, consequently, extravasation. However, it is noteworthy that, when intravenous CT administration is required in continuous infusion, install the medicine by infusion pump, strictly at the prescribed time and according to schedule, after always blocking the infusion pump to avoid accidental modifications of the infusion pump. programming. Low dose $\mathrm{CT}$ with infusion time up to 1 hour may be drip infused ${ }^{(17,30-31)}$.

Currently, there are some documented management strategies that can be used after antineoplastic drug extravasation, depending on the category of extravasated drug, volume and site of extravasation, local knowledge, and historical practice within institutions (cold or hot compress application, use of various antidotes, surgical intervention $)^{(9,17,28,30)}$.

In this sense, studies pointed to the need to have an extravasation kit containing instructions, materials and medicines always available $\mathrm{e}^{(18,29-31)}$. Early multidisciplinary assessment by oncology nurse specialists, oncology physicians and surgeons was recommended whenever necessary ${ }^{(28,30-31)}$

Regarding specific measures (antidotes), different suggestions have been published as possible topical or injected pharmacological methods for certain vesicant antineoplastic drugs ${ }^{(18,30)}$.

From this perspective, although there is no evidence to suggest a more effective management strategy than the other, international societies (American Society of Clinical Oncology, European Society of Medical Oncology, Oncology Nursing Society, and European Oncology Nursing Society) have published guidelines favoring the use of antidotes as opposed to saline washout ${ }^{(18,30)}$. One publication stated that there is little experience using the saline washout technique, so the saline wash technique can be used, however, this approach requires expert advice ${ }^{(30)}$.

As for the dexrazoxane antidote, as stated earlier, it is the only antidote licensed for the treatment of anthracycline extravasation $^{(19,20-21,27,30-31)}$. Systemic treatment with this drug has recently proven to be significantly protective before extravasation of other 
anthracyclines such as amrubicin, mitoxantrone and doxorubicin ${ }^{(30)}$. It should be administered intravenously into a large vein away from the site of anthracycline drug extravasation ${ }^{(20,27,30)}$. It should be noted that anthracyclines are more prone to sequelae than Vinca Alkaloids, taxanes and platinum compounds ${ }^{(28)}$.

Regarding DMSO, which is a tissue-penetrating solvent when applied topically, it is noted that it has free radical scavenging properties and has the ability to accelerate the removal of extravasated drugs from tissues ${ }^{(25)}$. Topical cooling needs to be removed 15 minutes before and during DMSO administration ${ }^{(25,31)}$.

In several animal experiments, sodium thiosulfate was unable to prevent mecloretamine skin toxicity when administered intravenously immediately before or after extravasation. However, when administered immediately after intradermal extravasation, it had a protective effect ${ }^{(30)}$.

As for hyaluronidase antidote, an enzyme that degrades hyaluronic acid, improving absorption of extravasated drugs, it may be effective in preventing skin necrosis due to Vinca Alkaloid extravasation and around taxane extravasation ${ }^{(28,30)}$.

According to some health institutions, topical corticosteroids may be used to reduce inflammation around the extravasation site ${ }^{(17)}$. However, there is no evidence that extravasation is an inflammatory process ${ }^{(17,28,30)}$. In addition, it has been reported that the use of corticosteroids may aggravate tissue damage caused by extravasation of Vinca Alkaloids and epipodophyllotoxins. It is noteworthy that the administration of systemic corticosteroids is not recommended for the treatment of extravasation of $C T^{(17,28,30)}$.

It is worth mentioning that documentation of extravasation is a high priority, since it provides information about the event and highlights possible deficits in care ${ }^{(9,16-31)}$, bringing contributions to continuous improvement in care, in addition to protect professionals involved in legal matters ${ }^{(16-17,20-22,)}$. Documentation may change by institution, but is required in many countries, including Brazil(17,23,25). Continuous monitoring at baseline and during antineoplastic agent infusion is essential every five to ten minutes ${ }^{(8)}$.

Follow-up of cases of extravasation of CT is needed ${ }^{(9,16-31)}$. The document must be structured so that it starts from the starting point of the event, followed by actions taken ${ }^{(17,24,28)}$, in addition to the complete evaluation and description of the area, with a photograph of the event ${ }^{(24-25,30-31)}$. It will also need to contain all actions taken ${ }^{(9,16-31)}$. Failure to perform or incorrect documentation can be interpreted as non-compliance with the institution's protocols, showing a reduction in the quality of care ${ }^{(17,30-31)}$, in addition to having legal implications for the professional.

The records made in the patient's medical record are a legal document of defense of the professionals, therefore, need to be instilled of effectiveness and legal sense. They reflect the nurse's commitment and workforce, valuing his interventions ${ }^{(32)}$.

Documentation should not be exclusively in case of $A E$, but throughout the CT administration process. All steps of the CT session, including records of the patient's condition before, during and after receiving the $\mathrm{CT}$, guidance provided, venous catheter insertion site, access conditions, latency extravasation response) and patient responses as well as extravasation events ${ }^{(17,21,30)}$.

It is believed that one of the strengths of this scoping review was the variety of countries and journals, as well as quantitative, qualitative and mixed approaches, and increased familiarity with the extravasation process. The available treatments and training of nurses administering $\mathrm{CT}$, whether or not an oncology specialist, will help ensure optimal management of extravasation.

\section{Study limitations}

There are some limitations to the scoping review process. There are searches published in other languages that have not been included, as well as not considering a diversity of studies likely to exist in other indexing databases.

\section{Contributions to nursing}

The importance of education and training of the oncologic nursing team for prevention and prompt pharmacological and non-pharmacological management is highlighted. The findings reinforce the need for knowledge about the adversities arising from cancer treatment for comprehensive and resolute care, especially by nurses. He is responsible for identifying and alerting irregularities, providing clarifications to patients and families, and organizing and supervising nursing care.

\section{CONCLUSIONS}

The present study summarized the main results and recommendations of research on prevention and management of extravasation of antineoplastic agents in adult patients. It was noticed in this scoping review that there is a lack of studies, especially those with higher level of evidence such as clinical trials, meta-analyzes, which bring more support to the problem of extravasation of antineoplastic agents.

The major emphasis was on prevention above all conduct due to global efforts in health care safety for all patients. It is the strategies that seek to prevent and prevent outcomes from $A E$, such as extravasation of $\mathrm{CT}$, that are paramount to patient safety.

Other highlights were the implementation of evidence-based protocols, continuing education, nursing staff training, standardization of care techniques and processes in order to systematize care for cancer patients, providing greater safety and quality of services provided.

It is noteworthy that no studies comparing the use of different strategies, such as the result of the use of saline solution compared to the use of antidotes, were identified, however these differ according to the extravasated antineoplastic agent.

Through the conduct, the main focus was to act as soon as possible, either in the identification of extravasation of CT; in the decision-making of the professional in the face of this complication, in order to reduce the chances of sequelae and greater problems for the individual, as well as in the proper documentation.

\section{FUNDING}

This study was financed in part by the Coordination for the Improvement of Higher Education Personnel - Brazil (CAPES Coordenação de Aperfeiçoamento de Pessoal de Nível Superior) - Finance Code 001. 


\section{REFERENCES}

1. Na Z, Qiaoyuan Y, Binghan W, Qin Z, Yue C, Xin P, et al. A developed model of cancer patient participation in intravenous chemotherapy safety. Oncotarget [Internet]. 2017 [cited 2018 Aug 17];8(50):87598-606. Available from: https://www.ncbi.nlm.nih.gov/pmc/articles/PMC5675656/

2. Lopes LD, Rodrigues AB, Brasil DRM, Moreira MMC, Amaral JG, Oliveira PP. Prevention and treatment of mucositis at an oncology outpatient clinic: a collective construction. Texto Contexto Enferm [Internet]. 2016 [cited 2017 Nov 12]; 25(1): e2060014. Available from: http://www. scielo.br/pdf/tce/v25n1/0104-0707-tce-25-01-2060014.pdf

3. Instituto Nacional de Câncer José Alencar Gomes da Silva (INCA). Coordenação de Prevenção e Vigilância. Estimativa 2018: incidência de câncer no Brasil [Internet]. Rio de Janeiro: INCA, 2017 [cited 2018 Dec 22]. Available from: http://www1.inca.gov.br/inca/Arquivos/ estimativa-2018.pdf

4. Cardoso ACLR, Araújo DD, Chianca TCM. Risk prediction and impaired tactile sensory perception among cancer patients during chemotherapy. Rev Latino-Am Enfermagem [Internet]. 2017 [cited 2018 Aug 17];25:e2957. Available from: http://www.scielo.br/pdf/rlae/ v25/pt_0104-1169-rlae-25-e2957.pdf

5. Bernabeu-Martínez MA, Ramos Merino M, Santos Gago JM, Álvarez-Sabucedo LM, Wanden-Berghe C, Sanz-Valero J. Guidelines for safe handling of hazardous drugs: a systematic review. PLoS One [Internet]. 2018 [cited 2018 Aug 05];13(5):e0197172. Available from: http:// journals.plos.org/plosone/article?id=10.1371/journal.pone.0197172

6. Looper K, Winchester K, Robinson D, Price A, Langley R, Martin G, et al. Best practices for chemotherapy administration in pediatric oncology. J Pediatr Oncol Nurs [Internet]. 2016 [cited 2018 Aug 05];33(3):165-72. Available from: https://doi-org.ez18.periodicos.capes.gov. $\mathrm{br} / 10.1177 / 1043454215610490$

7. Silva SMO, Alves IDF, Silva TM, Brandão CP, Santos AG. Levantamento dos índices de extravasamento de quimioterápicos no ambulatório de quimioterapia do centro de assistência de alta complexidade de oncologia (CACON) - HUPAA. Gep News [Internet]. 2018 [cited 2018 Aug 05];1(1): 172-7. Available from: http://www.seer.ufal.br/index.php/gepnews/article/view/4706/3310.

8. Kreidieh FY, Moukadem HA, Saghir NSE. Overview, prevention and management of chemotherapy extravasation. World J Clin Oncol [Internet]. 2016 [cited 2018 Nov 01];7(1):87-97. Available from: https://www.ncbi.nlm.nih.gov/pmc/articles/PMC4734939/

9. Jackson-Rose J, Del Monte J, Groman A, Dial LS, Atwell L, Graham J, et al. Chemotherapy Extravasation: establishing a national benchmark for incidence among Cancer Centers. Clin J Oncol Nurs [Internet]. 2017 [cited 2018 Aug 05]; 21(4):438-45. Available from: http://dx.doi-org. ez18.periodicos.capes.gov.br/10.1188/17.CJON.438-445

10. Roop JC, Wu HS. Current practice patterns for oral chemotherapy: results of a national survey. Oncol Nurs Forum [Internet]. 2014 [cited 2018 Sep 05];41(2):185-94. Available from: http://dx.doi-org.ez18.periodicos.capes.gov.br/10.1188/14.0NF.41-02AP

11. Tricco AC, Lillie E, Zarin W, O'Brien KK, Colquhoun H, Levac D, et al. PRISMA Extension for Scoping Reviews (PRISMA-ScR): checklist and Explanation. Ann Intern Med [Internet]. 2018 [cited 2018 Oct 27];169(7):467-73. Available from: http://annals.org/aim/fullarticle/2700389/ prisma-extension-scoping-reviews-prisma-scr-checklist-explanation

12. Peters MDJ, Godfrey C, Mclnerney P, Baldini SC, Khalil H, Parker D. Chapter 11: Scoping Reviews. In: Aromataris E, Munn Z (Editors). Joanna Briggs Institute Reviewer's Manual [Internet]. The Joanna Briggs Institute. 2017 [cited 2018 Aug 05]. Available from: https:// reviewersmanual.joannabriggs.org/

13. Tricco AC, Lillie E, Zarin W, O'Brien K, Colquhoun H, Kastner M, et al. A scoping review on the conduct and reporting of scoping reviews. BMC Med Res Methodol [Internet]. 2016 [cited 2018 Aug 05];16:15. Available from: https://doi.org/10.1186/s12874-016-0116-4

14. Melnyk BM, Fineout-Overholt E. Evidence-based practice in nursing \& healthcare. A guide to best practice. 2a ed. Philadelphia: Lippincot Williams \& Wilkins; 2011.

15. Matsui $Y$, Murayama R, Tanabe H, Oe M, Motoo Y, Wagatsuma T, et al. Evaluation of the predictive validity of thermography in identifying extravasation with intravenous chemotherapy infusions. J InfusNurs [Internet]. 2017 [cited 2018 Aug 25];40(6):367-74. Available from: https://www.ncbi.nlm.nih.gov/pmc/articles/PMC5680995/.

16. Custódio, CS. Injurias vasculares relacionadas a infusão periférica de quimioterapia em mulheres com câncer de mama: estudo longitudinal [Dissertação]. Brasília (DF): Universidade de Brasília; 2016.

17. Freitas KABS. Estratégias para a administração segura de antineoplásicos [Dissertação]. Universidade Estadual Paulista, Faculdade de Medicina de Botucatu, Botucatu (SP); 2015.

18. Harrold K, Gould D, Drey N. The management of cytotoxic chemotherapy extravasation: a systematic review of the literature to evaluate the evidence underpinning contemporary practice. Eur J Cancer Care [Internet]. 2015 [cited 2018 Sep 28];24(6):771-800. Available from: https:// doi.org/10.1111/ecc.12363

19. Muthuramalingam S, Gale J, Bradbury J. Dexrazoxane efficacy for anthracycline extravasation: use in UK clinical practice. Int J Clin Pract [Internet]. 2013 [cited 2018 Sep 28];67(3):244-9. Available from: https://doi.org/10.1111/ijcp.12103

20. Harrold K, Gould D, Drey N. The efficacy of saline washout technique in the management of exfoliant and vesicant chemotherapy extravasation: a historical case series report. Eur J Cancer Care [Internet]. 2013 [cited 2018 Sep 28];22(2):169-78. Available from:https://doi. org/10.1111/ecc.12023 
21. Drake D. BET3: Emergency management of anthracycline extravasation. Emerg Med J [Internet]. 2012 [cited 2018 Sep 28]; 29(9):777-9. Available from:http://dx.doi.org/10.1136/emermed-2012-201686.4

22. Schneider F, Pedrolo E. Extravasation of antineoplastic drugs: assessment of the nursing team knowledge. Rev Min Enferm [Internet]. 2011 [cited 2018 July 25];15(4):522-9. Available from: http://www.reme.org.br/artigo/detalhes/66.

23. Adami NP, de Gutiérrez MG, da Fonseca SM, de Almeida EP. Risk management of extravasation of cytostatic drugs at the adult chemotherapy outpatient clinic of a University Hospital. J Clin Nurs [Internet]. 2005 [cited 2018 Sep 28];14(7):876-82. Available from: https://doi.org/10.1111/j.1365-2702.2005.01124.x

24. Tsavaris NB, Komitsopoulou P, Karagiaouris P, Loukatou P, Tzannou I, Mylonakis N, et al. Prevention of tissue necrosis due to accidental extravasation of cytostatic drugs by a conservative approach. Cancer Chemoth Pharm [Internet]. 1992 [cited 2018 Sep 28];30(4):330-3. Available from: https://link-springer-com.ez18.periodicos.capes.gov.br/content/pdf/10.1007\%2FBF00686305.pdf

25. Olver IN, Aisner J, Hament A, Buchanan L, Bishop JF, Kaplan RS. A prospective study of topical dimethyl sulfoxide for treating anthracycline extravasation. J Clin Oncol[Internet].1988[cited 201820 Dec];6(11):1732-5. Available from:https://doi.org/10.1200/JCO.1988.6.11.1732

26. Dougherty L, Oakley C. Advanced practice in the management of extravasation: Lisa Dougherty and Catherine Oakley report how chemotherapy nurses in south London have been trained in the flush-out technique. Cancer Nursing Practice [Internet]. 2011 [cited 2018 Sep 28];10(5):16-22. Available from: http://cancernursingpractice.rcnpublishing.co.uk/index.asp

27. Onesti MG, Carella S, Fioramonti P, Scuderi N. Chemotherapy extravasation management: 21-year experience. Ann Plast Surg [Internet]. 2017 [cited 2018 Sep 28];79(5):450-7. Available from: https://doi.org/10.1097/SAP.00000000000001248

28. Pluschnig U, Haslik W, Bayer G, Soleiman A, Bartsch R, Lamm W, et al. Outcome of chemotherapy extravasation in a large patient series using a standardised management protocol. Support Care Cancer [Internet]. 2015 [cited 2018 Sep 28];23(6):1741-8. Available from: https://link. springer.com/content/pdf/10.1007\%2Fs00520-014-2535-2.pdf

29. de Wit M, Ortner P, Lipp HP, Sehouli J, Untch M, Ruhnke M, et al. Management of cytotoxic extravasation - ASORS expert opinion for diagnosis, prevention and treatment. Onkologie [Internet]. 2013 [cited 2018 Sep 28];36(3):127-35. Available from: https://doi.org/10.1159/000348524

30. Pérez Fidalgo JA, García Fabregat L, Cervantes A, Margulies A, Vidall C, Roila F. ESMO Guidelines Working Group. Management of chemotherapy extravasation: ESMO-EONS Clinical Practice Guidelines. Ann Oncol [Internet]. 2012 [cited 2018 Sep 28];23(Suppl 7):vii167vii173. Available from: https://doi.org/10.1093/annonc/mds294

31. Wengström Y, Margulies A, European Oncology Nursing Society Task Force. European Oncology Nursing Society extravasation guidelines. Eur J Oncol Nurs [Internet]. 2008 [cited 2018 Sep 28];12(4):357-61. Available from: https://doi.org/10.1016/j.ejon.2008.07.003

32. Conselho Federal de Enfermagem. Resolução COFEN n 311, de 08 de fevereiro de 2007. Aprova a Reformulação do Código de Ética dos Profissionais de Enfermagem [Internet]. 2007 [cited 2019 Jun 28]. Available from: http://site.portalcofen.gov.br/node/4345 